\title{
Model Perjanjian Baku Pada Kontrak Berlangganan Sambungan Telekomunikasi Telepon Selular Pasca Bayar $^{1}$
}

\author{
Elis Herlina dan Sri Santi \\ Universitas Islam Nusantara Bandung \\ J1. Soekarno Hatta No. 530, Bandung, Jawa Barat \\ elisherlina1504@gmail.com
}

\begin{abstract}
The contract to subscribe to the telecommunication connection of postpaid cellular phone is a standard contract made by the business actor by almost not giving freedom at all to other parties to do negotiation for the requirements offered. This research is to study: first, is the implementation of standard contract for the subscription contract of telecommunication connection of postpaid cellular phone suitable with the legal principles of the contract? Second, how the model of standard contract in the contract of subscription for the telecommunication connection of the postpaid cellular phone is viewed from the contract laws and Law Number 8 of 1999 on the Consumer Protection? This is a normative-juridical research. The result of the research concluded that first; the subscription contract for the telecommunication connection of postpaid cellular phone theoretically has fulfilled the provisions of the Article 1320 Civil Law on the requirement of the contract legality. Second, the model of the subscription model of telecommunication connection of postpaid cellular phone must provide the clauses in accordance with the Law of Consumer Protection particularly limited with the Provision of Article 18 of Laws of Consumer Protection.
\end{abstract}

Keywords: Standard contract, telecommunication, consumer protection

\begin{abstract}
Abstrak
Perjanjian berlangganan sambungan telekomunikasi telepon selular pasca bayar merupakan perjanjian baku yang dibuat oleh pelaku usaha dengan hampir tidak memberikan kebebasan sama sekali kepada pihak lainnya untuk melakukan negosiasi atas syarat-syarat yang disodorkan. Penelitian ini mengkaji, pertama, apakah penerapan perjanjian baku pada kontrak berlangganan sambungan telekomunikasi telepon selular pasca bayar telah sesuai dengan prinsip-prinsip hukum perjanjian? Kedua, bagaimana model perjanjian baku pada kontrak berlangganan sambungan telekomunikasi telepon selular pasca bayar ditinjau dari hukum perjanjian dan Undang-Undang Nomor 8 Tahun 1999 tentang Perlindungan konsumen? Penelitian ini merupakan penelitian yuridis normatif. Hasil penelitian menyimpulkan, pertama: kontrak berlangganan sambungan telekomunikasi telepon selular pascabayar secara teoritis telah memenuhi ketentuan Pasal 1320 KUH Perdata mengenai syarat sahnya suatu perjanjian. Kedua, model kontrak berlangganan sambungan telekomunikasi telepon selular pasca bayar harus memuat klausul-klausul yang sesuai dengan UndangUndang Perlindungan Konsumen, khususnya dibatasi dengan ketentuan Pasal 18 Undang-Undang Perlindungan Konsumen.
\end{abstract}

Kata-kata kunci : perjanjian baku, telekomunikasi, perlindungan konsumen

${ }^{1}$ Hasil Penelitian Hibah Bersaing yang dibiayai oleh Dikti melalui DIPA Kopertis Wilayah IV Jawa Barat, Kemenristek Dikti, 2016. 


\section{Pendahuluan}

Dewasa ini banyak transaksi bisnis yang terjadi bukan melalui proses negosiasi yang seimbang diantara para pihak, tetapi perjanjian itu terjadi dengan cara pihak yang satu telah menyiapkan syarat-syarat baku pada suatu formulir perjanjian yang sudah dicetak dan kemudian disodorkan kepada pihak lainnya untuk disetujui dengan hampir tidak memberikan kebebasan sama sekali kepada pihak lainnya untuk melakukan negosiasi atas syarat-syarat yang disodorkan. Perjanjian ini dinamakan perjanjian standar atau perjanjian baku atau perjanjian adhesi. ${ }^{2}$ Perjanjian baku pada hakikatnya merupakan perjanjian yang telah distrandardisasi isinya oleh pihak ekonomi kuat, sedangkan pihak lainnya hanya diminta untuk menerima atau menolak isinya. Bila pihak lainnya menerima isi perjanjian tersebut, ia menandatangani perjanjian tersebut, tetapi bila ia menolak, perjanjian itu dianggap tidak ada, karena tidak menandatangani perjanjian tersebut. ${ }^{3}$ Oleh karena itu, hanya tinggal memilih antara menerima atau menolak (take it or leave it) syarat-syarat perjanjian baku yang disodorkan kepadanya. Standar kontrak (standard of contract) berkaitan erat dengan perlindungan konsumen dan menjadi salah satu ruang lingkup pembahasan perlindungan konsumen, yaitu melindungi konsumen dari kemungkinan diterapkannya syarat-syarat yang merugikan atau tidak adil di dalam perjanjian. ${ }^{4}$ Pasal 18 Undang-Undang Perlindungan Konsumen membuat sejumlah larangan penggunaan klausula baku dalam standar kontrak. Larangan tersebut dikaitkan dengan dua hal, yaitu isi dan bentuk penulisannya. Dari segi isinya, dilarang menggunakan standar kontrak yang memuat klausulaklausula yang tidak adil, sedangkan dari segi bentuk penulisannya, klausulakalusula itu harus dituliskan dengan sederhana, jelas dan terang, sehingga dapat dibaca dan dimengerti dengan baik oleh konsumen. ${ }^{5}$

Berdasarkan perspektif Hukum Perjanjian, Kontrak Berlangganan Sambungan Telekomunikasi Telepon Selular Pasca Bayar merupakan perjanjian

2 Sutan Remy Sjahdeini, Kebebasan Berkontrak dan Perlindungan Yang Seimbang bagi Para Pibak Dalam Perjanjian Kredit Bank Indonesia, Institut Bankir Indonesia, Jakarta, 1993, hlm. 66. hlm.147.

3 Salim HS, Perkembangan Hukum Kontrak di Luar KUH Perdata, PT Raja Grafindo Persada, Jakarta, 2006,

${ }^{4}$ Janus Sidabalok, Hukum Perlindungan Konsumen di Indonesia, PT Citra Aditya Bakti, Bandung, 2006, hlm. 14.

5 Ibid, hlm. 27. 
baku yang dibuat secara sepihak oleh operator dengan hampir tidak memberikan kebebasan sama sekali kepada konsumen untuk melakukan negosiasi atas syaratsyarat yang disodorkan. Oleh karena itu, keabsahan kontrak tersebut layak untuk dipertanyakan apakah prinsip-prinsip hukum perjanjian dalam kontrak tersebut telah dipenuhi. Hal ini misalnya, apakah elemen-elemen kontrak yang terdapat dalam Pasal 1320 KUH Perdata telah terpenuhi. Selain itu pasal-pasal lain yang terkait, misalnya Pasal 1338 (1) yang mengandung azas kebebasan berkontrak dan Pasal 1338 (3) yang memuat azas iktikad baik juga telah terpenuhi. Sedangkan dari perspektif Hukum Perlindungan Konsumen, Kontrak Berlangganan Sambungan Telekomunikasi Telepon Selular Pasca Bayar sangat berpotensi untuk menjadi perjanjian dengan klausula yang berat sebelah dan mengandung unsur-unsur yang tidak adil bagi konsumen. Selain itu, secara sekilas tampak jelas bahwa kontrak tersebut penulisannya jauh dari kriteria sederhana, jelas dan terang, sehingga sangat mungkin konsumen tidak dapat mengerti dengan baik isi dari kontrak tersebut. Dengan demikian, kontrak tersebut sangat berpotensi untuk melanggar Pasal 18 Undang-Undang Perlindungan Konsumen.

Penelitian ini mengkaji lebih dalam tentang seberapa besar potensi ketidaksesuaian Kontrak Berlangganan Sambungan Telekomunikasi Telepon Selular Pasca Bayar dengan prinsip-prinsip hukum perjanjian sebagaimana diatur dalam KUH Perdata, khususnya Pasal 1320 dan Pasal 1338. Selain itu, penelitian ini juga mengkaji kemungkinan untuk mengembangkan model perjanjian baku pada Kontrak Berlangganan Sambungan Telekomunikasi Telepon Selular Pasca Bayar yang di satu sisi tidak melanggar prinsip-prinsip hukum perjanjian dan di sisi lain dapat mengakomodasi dan memberikan perlindungan terhadap konsumen. Oleh karena itu, penelitian ini sangat signifikan dilakukan dan hasilnya akan ditawarkan kepada para pengambil kebijakan dan para pelaku bisnis serta masyarakat umum sebagai konsumen dengan harapan dapat menjadi pemicu terjadinya perubahan dalam pengembangan kontrak baku ke arah yang lebih baik. 


\section{Rumusan Masalah}

Berdasarkan uraian tersebut di atas, maka permasalahan dalam penelitian ini adalah: pertama, apakah penerapan perjanjian baku pada kontrak berlangganan sambungan telekomunikasi telepon selular pasca bayar telah sesuai dengan prinsip-prinsip hukum perjanjian? Kedua, bagaimana model perjanjian baku pada kontrak berlangganan sambungan telekomunikasi telepon selular pasca bayar ditinjau dari hukum perjanjian dan Undang-Undang Nomor 8 Tahun 1999 tentang Perlindungan konsumen?

\section{Tujuan Penelitian}

Adapun tujuan dari penelitian ini adalah: pertama, mengetahui dan mengkaji apakah perjanjian baku pada kontrak berlangganan sambungan telekomunikasi telepon selular pasca bayar telah sesuai dengan prinsip-prinsip hukum perjanjian. Kedua, mengetahui model perjanjian baku pada kontrak berlangganan sambungan telekomunikasi telepon selular pasca bayar ditinjau dari hukum perjanjian dan Undang-Undang Nomor 8 Tahun 1999 Tentang Perlindungan konsumen.

\section{Metode Penelitian}

Penelitian ini merupakan penelitian yuridis normatif, yaitu peneltian yang menitikberatkan kepada data sekunder atau data kepustakaan. ${ }^{6}$ Penelitian ini bersifat deskriptif analitis, yaitu penelitian dengan menyampaikan gambaran mengenai fakta-fakta yang ada ditunjang dengan ketentuan-ketentuan yang berlaku dan diterapkan.7 Teknik pengumpulan data dilakukan dengan penelitian kepustakaan (library research), yaitu mengumpulkan data sekunder yang menggunakan bahan hukum primer, sekunder, dan tersier. Wawancara dilakukan sebagai data penunjang. Data yang diperoleh dianalisis dengan menggunakan metode deskriptif kualitatif. ${ }^{8}$

$$
10 .
$$

${ }^{6}$ Ronny Hanitijo Soemitro, Metodologi Penelitian Hukum dan Juritmetri, Ghalia Indonesia, Jakarta, 1990, hlm.

7 Soerjono Soekanto, Pengantar Penelitian Hukum, Universitas Indonesia Pers, Jakarta, 1986, hlm. 86. hlm. 24-25.

${ }^{8}$ Maria S.W. Sumardjono, Pedoman Pembuatan Usulan Penelitian, Fakultas Hukum UGM, Yogyakarta, 1989, 


\section{Hasil Penelitian dan Pembahasan}

\section{Perjanjian Baku pada Kontrak Berlangganan Sambungan Telekomunikasi Telepon Selular Pasca Bayar Ditinjau dari Hukum Perjanjian}

Praktik penggunaan standar kontrak menimbulkan masalah hukum, bukan saja mengenai keadilan yang dicerminkan pada hak dan kewajiban para pihak, melainkan juga keabsahan perjanjian itu sendiri dan oleh hukum diragukan apakah benar-benar ada elemen kata sepakat yang merupakan syarat sahnya perjanjian dalam perjanjian baku tersebut. Syarat sahnya perjanjian yang harus ditinjau sehubungan dengan adanya perjanjian baku ini, antara lain syarat causa yang halal, terutama jika ada unsur penyalahgunaan keadaan, serta syarat kesepakatan kehendak, terutama jika ada keterpaksaan atau ketidakjelasan bagi salah satu pihak. ${ }^{9}$ Kesepakatan yang didapat dalam perjanjian itu merupakan hasil negosiasi di antara para pihak. Kata sepakat itu sendiri pada dasarnya adalah pertemuan antara dua kehendak. ${ }^{10}$ Proses semacam ini tidak ditemukan dalam perjanjian baku. Praktik tersebut di satu sisi sangat menguntungkan pengusaha, namun di sisi lain menimbulkan kerugian bagi konsumen. ${ }^{11}$ Sutan Remy Sjahdeini berpendapat bahwa perjanjian baku adalah perjanjian yang hampir seluruh klausul-klausulnya sudah dibakukan oleh pemakainya dan pihak yang lain pada dasarnya tidak mempunyai peluang untuk merundingkan atau meminta perubahan. Yang belum dibakukan hanyalah beberapa hal saja, misalnya yang menyangkut jenis, harga, jumlah, warna, tempat, waktu dan beberapa hal lainnya yang spesifik dari obyek yang diperjanjikan. Dengan kata lain, yang dibakukan bukan formulir perjanjian tersebut, tetapi klausul-klausulnya. ${ }^{12}$

Berkaitan dengan objek penelitian ini, maka peneliti akan mengidentifikasi apakah kontrak berlangganan sambungan telekomunikasi telepon selular ini merupakan perjanjian baku atau tidak dan akan membahasnya berdasarkan pendapat para ahli tentang ciri-ciri perjanjian baku.

\footnotetext{
${ }^{9}$ Ibid, hlm. 76.

${ }_{10}$ Ridwan Khairandy, Hukum Kontrak Indonesia dalam Perspektif Perbandingan, FH UII Press, Yogyakarta, 2014, hlm. 169.

11 R.M. Panggabean, "Keabsahan Perjanjian dengan Klausul Baku" JURNAL HUKUM IUS QUIA IUSTUM, No. 4 Vol. 17, Oktober 2010, hlm. 652.

${ }^{12}$ Sutan Remy Sjahdeini, Op. Cit., hlm. 66
} 
Menurut Mariam Darus Badrulzaman ciri-ciri perjanjian baku meliputi halhal sebagai berikut $:^{13} 1$. isinya ditetapkan secara sepihak oleh pihak yang posisi (ekonominya) kuat; 2. masyarakat (debitur) sama sekali tidak ikut bersama-sama menentukan isi perjanjian; 3. terdorong oleh kebutuhannya debitur terpaksa menerima perjanjian itu; 4 . bentuk tertentu (tertulis); 5 . dipersiapkan secara massal dan kolektif. Bila dikaitkan dengan ciri yang pertama, maka kontrak berlangganan sambungan telekomunikasi telepon selular pasca bayar telah memenuhi ciri pertama, karena isi dari kontrak ini ditetapkan secara sepihak oleh pelaku usaha. Selain itu juga telah memenuhi ciri yang kedua, karena masyarakat dalam hal ini pelanggan/konsumen tidak diikutsertakan menentukan isi perjanjian, perusahaan telekomunikasi secara sepihak telah menentukan sendiri isi perjanjian tersebut, pelanggan hanya tinggal membaca dan memahami isi dari kontrak tersebut, sehingga pelanggan tidak mempunyai kesempatan lagi untuk melakukan tawar menawar terhadap isi kontrak yang dibuat secara sepihak oleh pengusaha.

Ditinjau dari ciri ketiga, maka kontrak berlangganan sambungan telekomunikasi telepon pasca bayar merupakan perjanjian baku, karena dalam kenyataannya pelanggan/konsumen memang terpaksa harus menerima ketentuan yang telah diatur dalam kontrak tersebut terdorong oleh kebutuhan akan layanan telekomunikasi. Kontrak berlangganan sambungan telekomunikasi telepon selular pasca bayar dibuat secara tertulis, dibuat dalam rangkap dua yang sama dan ditandatangani oleh kedua belah pihak. Ciri kelima dari perjanjian baku juga telah dipenuhi, karena kontrak ini telah dibuat secara massal dan berlaku sama bagi seluruh konsumen/pelanggan pengguna akses telekomunikasi selular.

Berdasarkan uraian di atas, maka kontrak berlangganan sambungan telekomunikasi telepon selular pasca bayar telah memenuhi ciri-ciri dari perjanjian baku. Hukum perjanjian di Indonesia menganut asas kebebasan berkontrak (Pasal 1338 KUH Perdata) dan asas ini harus dibatasi bekerjanya, agar perjanjian yang dibuat berlandaskan asas itu tidak merupakan perjanjian yang berat sebelah atau timpang. ${ }^{14}$ Pembatasan tersebut terdapat dalam Pasal 1320 KUH Perdata tentang

${ }_{13}$ Mariam Darus Badrulzaman, Perjanjian Baku (Standard), Perkembangannya di Indonesia, Bandung, Alumni, 1980, hlm. 11

${ }^{14}$ Sutan Remy Sjahdeini, Op. Cit., hlm. 71. 
syarat sahnya perjanjian, juga tidak bertentangan dengan moral dan ketertiban umum (Pasal 1337 KUH Perdata), serta kepatutan, kebiasaan, atau undang-undang (Pasal 1339 KUH Perdata).

Pasal 1320 Kitab Undang-Undang Hukum Perdata menyebutkan bahwa suatu perjanjian dianggap sah bila memenuhi empat syarat sebagai berikut: 1 . Sepakat mereka yang mengikatkan dirinya; 2. Kecakapan untuk membuat suatu perikatan; 3. Suatu hal tertentu; 4 . Suatu sebab yang halal.

Berkaitan dengan perjanjian baku pada kontrak berlangganan sambungan telekomunikasi telepon selular pasca bayar, peneliti akan menganalisa apakah kontrak tersebut telah memenuhi syarat sahnya perjanjian sebagaimana telah dikemukakan di atas. Menurut pandangan peneliti syarat pertama telah terpenuhi, karena kontrak tersebut mulai berlaku apabila pelaku usaha dan pelanggan telah sepakat mengenai isi perjanjian tersebut serta adanya tanda tangan kedua belah pihak dalam perjanjian tersebut. Agar tanda tangan dari masing-masing pihak tersebut berlaku sah sebagaimana ketentuan Pasal 1321 KUH Perdata, maka kesepakatan itu tidak boleh mengandung unsur-unsur kekhilafan yang dilakukan oleh salah satu pihak atau kedua belah pihak, juga tidak mengandung unsur-unsur paksaan atau penipuan yang dilakukan oleh salah satu pihak. Bila pihak pelanggan menandatangani perjanjian tersebut, berarti pelanggan sepakat terhadap ketentuan dalam perjanjian tersebut, namun karena tidak adanya atau terbatasnya kesempatan bagi salah satu pihak untuk menegosiasikan klausula-klausula dalam kontrak baku tersebut, maka masih disangsikan apakah isi kontrak tersebut memang benar seperti yang diinginkannya, sehingga disangsikan pula apakah benar ada kata sepakat daripadanya.

Mengenai syarat kedua sahnya perjanjian tergantung pada identitas diri dari konsumen/pelanggan sambungan telekomunikasi telepon selular pasca bayar. Dalam formulir permohonan berlangganan telepon selular ditegaskan, bahwa pelanggan harus melengkapi dengan foto copy identitas diri berupa KTP atau SIM. Bila pelanggan tersebut telah memenuhi syarat, maka syarat cakap bagi pihak dalam perjanjian ini telah dipenuhi. 
Syarat ketiga dan keempat dari sahnya suatu perjanjian, yaitu suatu hal tertentu dan sebab yang halal menurut pandangan peneliti telah dipenuhi, karena objek dari perjanjian tersebut jelas dan merupakan sesuatu yang halal, karena tidak bertentangan dengan peraturan perundang-undangan, kesusilaan dan ketertiban umum.

Berdasarkan uraian di atas dapat ditarik kesimpulan bahwa secara teoritis perjanjian baku pada kontrak berlangganan sambungan telekomunikasi telepon selular pasca bayar telah memenuhi ketentuan Pasal 1320 Kitab Undang-Undang Hukum Perdata, tetapi dalam prakteknya semua tergantung pada para pihak dalam perjanjian tersebut, apakah akan memenuhi ketentuan Pasal 1320 Kitab Undang-Undang Hukum Perdata tersebut atau tidak.

Model Perjanjian Baku pada Kontrak Berlangganan Sambungan Telekomunikasi Telepon Selular Pasca Bayar Ditinjau dari Hukum Perjanjian dan Undang-Undang Nomor 8 Tahun 1999 tentang Perlindungan konsumen

Pasal 18 Undang-Undang Perlindungan Konsumen memberikan pembatasan dalam pencantuman klausula baku dalam suatu perjanjian baku, sebagai berikut: (1) Pelaku usaha dalam menawarkan barang dan/atau jasa yang ditujukan untuk diperdagangkan dilarang membuat atau mencantumkan klausula baku pada setiap dokumen dan/atau perjanjian apabila : a. Menyatakan pengalihaan tanggung jawab pelaku usaha; b. Menyatakan bahwa pelaku usaha berhak menolak penyerahan kembali barang yang dibeli konsumen; c. Menyatakan bahwa pelaku usaha berhak menolak penyerahan kembali uang yang dibayarkan atas barang dan/atau jasa yang dibeli oleh konsumen; d. Menyatakan pemberian kuasa dari konsumen kepada pelaku usaha, baik secara langsung maupun tidak langsung untuk melakukan segala tindakan sepihak yang berkaitan dengan barang yang dibeli oleh konsumen secara angsuran; e. Mengatur perihal pembuktian atas hilangnya kegunaan barang atau pemanfaatan jasa yang dibeli oleh konsumen; f. Memberi hak kepada pelaku usaha untuk mengurangi manfaat jasa atau mengurangi harta kekayaan konsumen yang menjadi objek jual beli jasa; g. Menyatakan tunduknya konsumen kepada peraturan yang berupa aturan baru, tambahan, lanjutan, dan/atau pengubahan lanjutan yang dibuat sepihak oleh pelaku usaha dalam masa konsumen memanfaatkan jasa yang dibelinya; h. Menyatakan bahwa konsumen memberi kuasa kepada pelaku usaha 
untuk pembebanan hak tanggungan, hak gadai, atau hak jaminan terhadap barang yang dibeli oleh konsumen secara angsuran. (2) Pelaku usaha dilarang mencantumkan klausula baku yang letak atau bentuknya sulit terlihat atau tidak dapat dibaca secara jelas, atau yang pengungkapannya sulit dimengerti. (3) Setiap klausula baku yang telah ditetapkan oleh pelaku usaha pada dokumen atau perjanjian yang memenuhi ketentuan sebagaimana dimaksud pada ayat (1) dan ayat (2) dinyatakan batal demi hukum. (4) Pelaku usaha wajib menyesuaikan klausula baku yang bertentangan dengan undang-undang ini.

Kontrak berlangganan sambungan telekomunikasi telepon selular pasca bayar ditetapkan secara sepihak oleh pelaku usaha, sehingga terdapat klausula yang merugikan pelanggan, antara lain :

\section{Ketentuan mengenai Pembatasan Tanggung Jawab Pelaku Usaha}

Berdasarkan hasil penelitian diperoleh data bahwa dalam beberapa ketentuan dan syarat berlangganan layanan telekomunikasi pascabayar terdapat klausul yang menyatakan bahwa pelaku usaha tidak bertanggung jawab terhadap pelanggan atas tuntutan, biaya-biaya kerusakan, kerugian atau tanggung jawab atas kerusakan atau kerugian atau hilangnya harta benda sehubungan dengan jasa telekomunikasi seluler yang diberikan pelaku usaha, tidak bertanggung jawab terhadap kegagalan penggunaan jasa telekomunikasi selular yang timbul dari kegagalan atau kerusakan yang terjadi pada jaringan telekomunikasi milik pelaku usaha atau yang dioperasikan oleh pihak lain, termasuk dalam hal pelanggan melakukan panggilan ke operator lain, sambungan langsung internasional dan atau dalam posisi roaming internasional serta tidak bertanggung jawab terhadap kerugian tidak langsung yang diderita oleh pelanggan termasuk hilangnya keuntungan yang diharapkan, kehilangan data dan kerugian tidak langsung lainnya yang timbul sehubungan dengan kegagalaan pelanggan dalam menggunakan jasa telekomunikasi selular yang disediakan oleh pelaku usaha. Hal ini jelas merugikan dan memberatkan pelanggan, karena tidak berfungsinya sambungan telekomunikasi bukan kesalahan dari pelanggan, tetapi menjadi 
tanggung jawab pelaku usaha, sehingga seharusnya tidak dialihkan kepada pelanggan.

Bila kita perhatikan Pasal 1246 KUH Perdata sebetulnya pelanggan berhak memperoleh ganti kerugian meliputi kerugian yang nyata-nyata diderita dan keuntungan yang seharusnya diperoleh, atau dengan pengertian lain meliputi biaya dan bunga. Oleh karena itu, bila pelanggan mengalami kerugian yang disebabkan tidak berfungsinya jaringan telekomunikasi sebagaimana mestinya padahal pelanggan telah membayar tagihan sesuai dengan tarifnya, maka ganti rugi yang memadai adalah dengan memperkirakan keuntungan yang seharusnya diperoleh apabila jaringan tidak mengalami gangguan.

Berkaitan dengan hal ini, Pasal 1339 KUH Perdata menentukan bahwa persetujuan-persetujuan tidak hanya mengikat untuk hal-hal yang dengan tegas dinyatakan di dalamnya, tetapi juga untuk segala sesuatu yang menurut sifat persetujuan, diharuskan oleh kepatutan, kebiasaan atau undang-undang. Sutan Remy Sjahdeini berpendapat bahwa kepatutan mempunyai isi yang lebih luas dari moral dan ketertiban umum, artinya bahwa apa yang tidak sesuai dengan moral dan melanggar ketertiban umum adalah juga tidak sesuai dengan kepatutan. Selain itu, keadilan dapat dimasukkan dalam arti kepatutan, sehingga sesuatu yang tidak adil berarti tidak patut. Dengan kata lain, bila dikaitkan dengan kepatutan dalam arti keadilan, maka isi atau klausul-klausul suatu perjanjian tidak boleh tidak adil. Klausul-klausul perjanjian yang secara tidak wajar sangat memberatkan pihak lainnya merupakan syarat-syarat yang bertentangan dengan keadilan. ${ }^{15}$ Klausula yang membatasi/meniadakan tanggung jawab pelaku usaha atas resiko tertentu yang mungkin timbul di kemudian hari disebut klausula eksonerasi/exemption clause. ${ }^{16}$ Keberadaan klausula eksonerasi dalam kontrak standar dinilai bertentangan dengan asas itikad baik. ${ }^{17}$

${ }^{15}$ Sutan Remy Sjahdeini, Op. Cit., hlm. 120.

${ }^{16}$ Johanes Gunawan, Penggunaan Perjanjian Standar dan Implementasinya pada Asas Kebebasan Berkontrak, Majalah Pro Justitia, Universitas Katholik Parahyangan, Bandung,1987, hlm. 71. Lihat juga Paripurna P. Sugarda, “Kontrak Standar: Antara Prinsip Kehati-hatian Bank dan Perlindungan Nasabah Debitur” MIMBAR HUKUM Vol. 20, No. 2, Juni 2008, hlm. 194.

${ }^{17}$ I Kadek MapraBawa Manda, “Aspek Hukum Perjanjian Berlangganan Telkom Flexy di Kota Palu”, Jurnal Ilmu Hukum Legal Opinion Edisi 4, Volume 3, Tahun 2015. 
Demikian pula pengalihan tanggung jawab dari pelaku usaha kepada pelanggan bertentangan dengan keadilan, serta melanggar Pasal 18 ayat (1) huruf a tentang pengalihan tanggung jawab pelaku usaha.

\section{Kewenangan Pelaku Usaha Menyatakan Konsumen/Pelanggan Wanprestasi dengan Langsung Mengenakan Sanksi}

Pengakhiran kontrak ditemukan dalam ketentuan berlangganan sambungan telekomunikasi telepon selular yang menentukan bahwa pelaku usaha dapat melakukan pengakhiran atau penghentian sementara secara sepihak baik terhadap sebagian maupun seluruh layanan jasa telekomunikasi selular yang diberikan oleh pelaku usaha kepada pelanggan. Sebaliknya pelanggan juga dapat melakukan pengakhiran penyediaan jasa telekomunikasi selular setiap saat dengan persetujuan tertulis lebih dahulu dari pelaku usaha. Pengakhiran penyediaan jasa telekomunikasi selular tidak menghapuskan kewajiban pelanggan hingga pengakhiran tersebut berlaku efektif. Pelaku usaha memiliki hak untuk mengajukan tuntutan perdata dan/atau pidana kepada pelanggan, termasuk namun tidak terbatas pada tuntutan untuk mendapatkan seluruh biaya-biaya yang terhutang dan penggantian atas kerugian yang diderita oleh pelaku usaha. Dari ketentuan tersebut jelas terlihat adanya pengalihan tanggung jawab pelaku usaha yang merupakan klausula yang dilarang untuk dicantumkan dalam perjanjian baku.

\section{Kewenangan Pelaku Usaha untuk Mengakhiri Kontrak Secara Sepihak dengan Mengesampingkan Ketentuan Pasal 1266 KUH Perdata}

Pelaku usaha dapat mengakhiri kontrak secara sepihak, karena dikenakannya sanksi pencabutan atau karena pelaku usaha tidak mampu lagi menjadi penyelenggara telekomunikasi di wilayah/lokasi pelanggan. Pengakhiran kontrak dilakukan dengan mengesampingkan berlakunya ketentuan Pasal 1266 Kitab Undang-Undang Hukum Perdata, sehingga pengakhiran kontrak dapat dilakukan oleh salah satu pihak dan dinyatakan sah tanpa menunggu keputusan hakim. Klausul tersebut menyebutkan pasal, tetapi tidak memuat isi pasal, sehingga pelanggan/konsumen yang tidak mengetahui isi pasal yang dimaksud, tidak dapat mengetahui dengan jelas tentang haknya untuk mendapat perlindungan hukum melalui pasal yang disimpangi. 
Pasal 1266 Kitab Undang-Undang Hukum Perdata berbunyi:

"Syarat batal dianggap selamanya dicantumkan dalam perjanjian-perjanjian yang timbal balik, manakala salah satu pihak tidak memenuhi kewajibannya. Dalam hal demikian perjanjian tidak batal demi hukum, tetapi pembatalan harus dimintakan kepada hakim.

Permintaan ini juga harus dilakukan, meskipun syarat batal mengenai tidak dipenuhinya kewajiban itu dinyatakan dalam perjanjian.

Jika syarat batal tidak dinyatakan dalam perjanjian, hakim leluasa menurut keadaan atas permintaan si tergugat, untuk memberikan suatu jangka waktu guna kesempatan memenuhi kewajibannya, jangka waktu mana tidak boleh lebih dari satu bulan".

Ketentuan Pasal 1266 Kitab Undang-Undang Hukum Perdata tersebut terlihat bahwa meskipun syarat batal mengenai tidak dipenuhinya kewajiban dinyatakan dalam perjanjian, putusan hakim mengenai pembatalan perjanjian tetap diperlukan. Namun demikian, karena ketentuan dalam Buku III Kitab UndangUndang Hukum Perdata hanya bersifat mengatur (aanvullend recht) dan bukan bersifat memaksa, maka para pihak dapat menyimpangi ketentuan tersebut berdasarkan kesepakatan. Penyimpangan terhadap pasal tersebut seharusnya tetap dijelaskan, sehingga pelanggan/konsumen dapat membaca dengan jelas apa yang dimaksud dalam klausula tersebut.

Pasal 18 ayat (2) Undang-Undang Perlindungan Konsumen menentukan bahwa pelaku usaha dilarang mencantumkan klausula baku yang letak atau bentuknya sulit terlihat atau tidak dapat dibaca secara jelas, atau yang pengungkapannya sulit dimengerti. Berkaitan dengan pencantuman Pasal 1266 Kitab Undang-Undang Hukum Perdata tanpa penjelasan lebih lanjut, sehingga tidak dimengerti oleh pelanggan/konsumen, maka hal ini termasuk dalam klausula yang dilarang untuk dicantumkan dalam perjanjian baku.

Kontrak berlangganan telekomunikasi selular pascabayar ditulis dalam ukuran huruf yang kecil, sehingga sulit untuk dibaca secara jelas. Pelaku usaha dalam hal ini tidak mengindahkan keawaman pelanggan/konsumen, sehingga hak konsumen untuk memperoleh informasi yang benar, jelas dan jujur, hak untuk mendapat pembinaan dan pendidikan, serta hak untuk diperlakukan atau dilayani secara benar dan jujur tidak dipenuhi. 
Berdasarkan uraian di atas, maka menurut peneliti dalam kontrak berlangganan sambungan telekomunikasi selular pascabayar terdapat kalusulaklausula yang bertentangan dengan tujuan dari perlindungan konsumen sebagaimana diatur dalam Pasal 3 Undang-Undang Perlindungan Konsumen, bertentangan dengan ketentuan Pasal 4 butir c, f dan g Undang-Undang Perlindungan Konsumen, serta bertentangan dengan Pasal 18 ayat (1) huruf a dan Pasal 18 ayat (2) Undang-Undang Perlindungan Konsumen. Dengan demikian, apabila terjadi pelanggaraan terhadap pasal 18 ayat (1) dan ayat (2) UndangUndang Perlindungan Konsumen, maka dinyatakan batal demi hukum, dan pelaku usaha wajib menyesuaikan klausula baku yang bertentangan dengan Undang-Undang Perlindungan Konsumen tersebut.

Pasal 3 Undang-Undang Nomor 8 Tahun 1999 Tentang Perlindungan Konsumen menegaskan bahwa perlindungan konsumen bertujuan, antara lain:

Meningkatkan Pemberdayaan Konsumen Dalam Memilih, Menentukan, dan Menuntut hak-haknya sebagai Konsumen

Ketentuan berlangganan sambungan telekomunikasi telepon selular pascabayar seyogyanya dimulai dengan memperhatikan kepentingan-kepentingan konsumen yang dituangkan secara konkrit dalam perjanjian tersebut, karena ternyata dalam ketentuan tersebut konsumen dipaksakan untuk menyepakati bentuk, isi, dan syarat-syarat dari perjanjian baku yang telah dibuat secara sepihak oleh pelaku usaha. Klausula-klausula dalam kontrak tersebut lebih mengutamakan kepentingan pelaku usaha daripada kepentingan pelanggan, kewajiban yang dibebankan kepada pelanggan lebih banyak dibandingkan kewajiban pelaku usaha.

Menciptakan sistem Perlindungan Konsumen yang Mengandung Unsur Kepastian Hukum dan Keterbukaan Informasi Serta Akses untuk Mendapatkan Informasi

Berkaitan dengan tujuan perlindungan konsumen tersebut di atas, menurut pandangan peneliti kontrak berlangganan sambungan telekomunikasi telepon selular pascabayar belum mencerminkan dan mengarah kepada pencapaian tujuan yang demikian, karena terdapat klausul yang isinya kurang dimengerti oleh 
pelanggan, seperti tidak adanya penjelasan mengenai Pasal 1266 KUH Perdata. Klausula syarat batal yang mengesampingkan Pasal 1266 dan 1267 KUH Perdata merupakan bagian dari perkembangan hukum kontrak dimana pihak kreditur atau pelaku usaha ingin mengesampingkan permintaan pembatalan ke pengadilan untuk efisiensi. Klausula ini sering dianggap merugikan pihak yang lemah, yaitu debitur atau konsumen serta berfungsi untuk melindungi pihak kreditur di satu sisi, tetapi di sisi lain klausula ini merugikan konsumen ketika gagal melaksanakan prestasi. ${ }^{18}$

\section{Menumbuhkan Kesadaran Pelaku Usaha Mengenai Pentingnya Perlindungan Konsumen, sehingga Tumbuh Sikap yang Jujur dan Bertanggung Jawab dalam Berusaha}

Sikap yang jujur dan bertanggung jawab dalam berusaha bersumber dari adanya itikad baik dari pelaku usaha, sehingga pelaku usaha ikut bertanggung jawab untuk menciptakan iklim yang sehat dalam berusaha demi menunjang pembangunan nasional,19 Ketentuan tentang itikad baik ini diatur dalam Pasal 1338 ayat (3) KUH Perdata, bahwa perjanjian harus dilaksanakan dengan itikad baik. ${ }^{20}$ Dengan standar ini maka perilaku para pihak dalam melaksanakan kontrak dan penilaian terhadap isi kontrak harus didasarkan pada prinsip kerasionalan dan kepatutan. ${ }^{21}$ Berkaitan dengan hal ini, peneliti berpendapat bahwa tujuan tersebut belum tercapai dalam ketentuan berlangganan sambungan telekomunikasi telepon selular pascabayar, karena klausula-kalusula dalam perjanjian tersebut masih memperlihatkan sikap yang kurang jujur dari pelaku usaha. Dengan demikian, kontrak berlangganan sambungan telekomunikasi telepon selular pascabayar belum mencerminkan adanya tindakan yang dapat mewujudkan terciptanya tujuan dari perlindungan terhadap konsumen sebagaimana diatur dalam Pasal 3 Undang-Undang Nomor 8 Tahun 1999.

${ }^{18}$ Christopher Iskandar, Kekuatan Mengikeat Klausula Syarat Batal Dalam Kontrak Bisnis Yang Mengesampingkan Pasal 1266 dan 1267 KUH Perdata, Program Studi Magister Ilmu Hukum Fakultas Hukum Universitas Sumatra Utara, Medan, 2014.

19 Janus Sidabalok, Op. Cit., hlm. 93.

20 Abdul Halim Barkatulah, Hukum Perlindungan Konsumen Kajian Teoritis dan Perkembangan Pemikiran, Nusa Media, Bandung, 2008, Op. Cit., hlm. 38.

21 Ridwan Khairandy, "Iktikad Baik dalam Pelaksanaan Kontrak: Super Eminent Principle yang Memerlukan Pengertian dan Tolak Ukur Objektif” dalam JURNAL HUKUM IUS QULA IUSTUM, Vol. 14, No. 3, Juli, 2007, hlm. 356. 
Upaya yang dilakukan untuk mengurangi dominasi pelaku usaha adalah dengan menetapkan pembatasan terhadap isi klausula baku yang merupakan bagian dari suatu perjanjian baku dengan ketentuan Pasal 18 Undang-Undang Perlindungan Konsumen. Dengan demikian, setiap penerapan Pasal 1338 ayat (1) KUH Perdata harus selalu dihubungkan dengan Pasal 18 Undang-Undang Perlindungan Konsumen. Pembuatan perjanjian baku berdasarkan asas kebebasan berkontrak harus memperhatikan ketentuan-ketentuan pembatasan pencantuman kalusula baku yang diatur dalam Pasal 18 Undang-Undang Perlindungan Konsumen. Bila ketentuan pasal tersebut tidak diindahkan oleh pelaku usaha, maka klausula baku tersebut batal demi hukum. Adanya pembatasan pencantuman klausula baku juga memberikan kepastian hukum kepada pelaku usaha dalam menjalankan usahanya, karena sudah ada kepastian klausula baku seperti apa yang dilarang atau tidak boleh dicantumkan dalam perjanjian baku.

Adanya beberapa klausula baku dalam kontrak berlangganan sambungan telekomunikasi telepon selular pascabayar yang melanggar pembatasan klausula baku menurut Pasal 18 Undang-Undang Perlindungan Konsumen menunjukkan bahwa berlakunya Undang-Undang Perlindungan Konsumen belum dapat dilaksanakan secara optimal, karena ternyata masih terdapat klausula yang bersifat merugikan konsumen dengan memanfaatkaan kedudukan konsumen yang lebih lemah, sehingga asas keadilan yang menghendaki bahwa melalui pengaturan dan penegakan hukum perlindungan konsumen ini, konsumen dan produsen dapat berlaku adil melalui perolehan hak dan penunaian kewajiban secara seimbang belum dapat diwujudkan. Pasal 18 ayat (3) Undang-Undang Perlindungan Konsumen menegaskan bahwa setiap klausula baku yang ditetapkan oleh pelaku usaha pada dokumen atau perjanjian yang memenuhi ketentuan sebagaimana dimaksud pada Pasal 18 ayat (1) dan ayat (2) dinyatakan "batal demi hukum." Perlindungan konsumen juga tidak dapat dipisahkan dari tanggung jawab pelaku usaha. Pasal 19 ayat (1) Undang-Undang Perlindungan konsumen menyatakan bahwa pelaku usaha bertanggung jawab memberikan ganti rugi atas kerusakan, pencemaran, dan/atau kerugian konsumen akibat mengkonsumsi barang 
dan/atau jasa yang dihasilkan atau diperdagangkan. Oleh karena itu, tanggung jawab pelaku usaha meliputi tanggung jawab ganti kerugian atas kerusakan, tanggung jawab ganti kerugian atas pencemaran, dan tanggung jawab atas kerugian konsumen.22 Demikian pula pada kontrak berlangganan sambungan telekomunikasi telepon selular pascabayar, dasar gugatan untuk menggugat pelaku usaha untuk memperoleh ganti kerugian, yaitu melalui tuntutan berdasarkan wanprestasi merupakan suatu bentuk perlindungan konsumen yang minimal, karena gugatan konsumen hanya dibatasi pada hal-hal yang secara tegas diperjanjikan. Selain itu, tuntutan ganti kerugian atas kerugian yang dialami oleh konsumen dapat dilakukan berdasarkan perbuatan melawan hukum sesuai dengan Pasal 1365 Kitab Undang-Undang Hukum Perdata. Berkaitan dengan adanya klausul pengalihan tanggung jawab yang seharusnya menjadi tanggung jawab pelaku usaha dan menimbulkan kerugian pada pelanggan, pengakhiran kontrak secara sepihak oleh pelaku usaha yang menimbulkan kerugian, serta pelanggaraan terhadap hak-hak konsumen, peneliti berpendapat bahwa pelanggan dapat menuntut pelaku usaha atas dasar perbuatan melawan hukum dengan pertimbangan bahwa selain bertentangan dengan undang-undang (Pasal 18 ayat 1 a Undang-Undang Nomor 8 Tahun 1999 tentang Perlindungan Konsumen), melanggar hak orang lain, juga bertentangan dengan kepatutan. Oleh karena itu, perlu disesuaikan dan penggantian kerugian kepada konsumen prosesnya dipermudah. ${ }^{23}$ Pencantuman klausula baku tentang pengalihan tanggung jawab dari pelaku usaha kepada pelanggan pada kontrak berlangganan sambungan telekomunikasi telepon selular pascabayar menunjukkan telah terjadi pelanggaran terhadap Pasal 18 ayat (1) butir a Undang-Undang Perlindungan Konsumen, sehingga pelaku usaha diancam dengan pidana penjara paling lama 5 (lima) tahun atau pidana denda paling banyak Rp 2.000.000.000,00 (dua miliar rupiah). Selain itu, tulisannya sangat kecil, sehingga tidak dapat dibaca secara jelas.

${ }^{22}$ Ahmadi Miru \& Sutarman Yodo, Hukum Perlindungan Konsumen, PT Raja Grafindo Persada, Jakarta, 2004, Op. Cit., hlm. 126.

${ }^{23}$ Renny Supriyatni, Tanggung Jawab Pelaku Usaha PT. Telekomunikasi Indonesia Tbk. Atas Penggunaan Perjanjian Baku Dibubungkan Dengan Undang-Undang Nomor 8 Tabun 1999 Tentang Perlindungan Konsumen . 
Kreditur dilarang mencantumkan klausula baku yang letak dan bentuknya sulit dilihat, tidak dapat dibaca dengan jelas, pengungkapan bahasanya sulit dimengerti. ${ }^{24}$ Dengan demikian, pelaku usaha juga telah melanggar ketentuan Pasal 18 ayat (2) Undang-Undang Perlindungan Konsumen.

Dengan keluarnya Undang-Undang Perlindungan Konsumen, seharusnya pelaku usaha membuat penyesuaian yang tidak bertentangan dengan Pasal 18, tetapi pada kenyataannya pencantuman klausula baku yang dilarang UndangUndang Perlindungan Konsumen masih tetap dicantumkan. Berdasarkan penelitian, hal ini disebabkan karena kalangan pelaku usaha belum memahami adanya larangan terhadap perbuatan dan kebiasaan para pelaku usaha, khususnya terhadap pencantuman tentang klausul baku di dalam transaksi antara pelaku usaha dengan konsumen. Sebagian besar pelaku usaha mengatakan belum mengetahui hal itu, ada yang pernah mendengarnya, tetapi belum mengetahui peraturan apa yang mengaturnya. ${ }^{25}$ Berbicara mengenai hak, dari wawancara yang dilakukan terhadap konsumen, umumnya mereka menyangsikan bagaimana cara mendapatkan hak yang efektif, karena terlalu merepotkan kalau hanya menuntut masalah yang tidak banyak nilainya. Mengenai transaksi dalam jumlah besar sekali, tetapi ternyata merugikan konsumen, umumnya mereka akan menuntutnya. Sementara mengenai kemana mengadukannya, semuanya mengatakan tidak tahu, kecuali hanya mengetahui ke aparat kepolisian. Ketika dijelaskan bahwa dalam beberapa hal, klausul baku telah dilarang dicantumkan dan hal itu tidak perlu diakui, karena Undang-Undang Perlindungan Konsumen melarangnya, hampir seluruhnya mengatakan belum tahu bahwa ada peraturan yang melarang pencantuman klausul baku untuk transaksi perdagangan. Sebagian besar tidak mempersoalkan klausul baku yang ada, dan menerima begitu saja mengenai isi dari klausul baku itu, serta hanya membacanya sepintas. ${ }^{26}$ Selain itu,

\footnotetext{
${ }^{24}$ Rini Haryati, Subaidah Ratna Juita, Ani Triwati, Perlindungan Hukum Bagi Konsumen Dalam Perjanjian Pembiayaan Konsumen (Suatu Kajian Normatif), Laporan Penelitian. Fakultas Hukum Universitas Semarang, 2011.

${ }^{25}$ N. H. T. Siahaan, Hukum Konsumen Perlindungan Konsumen dan Tanggung Jawab Produk, Panta Rei, Jakarta, 2005, hlm. 44.

${ }^{26}$ Loc. Cit.
} 
upaya yang dapat dilakukan untuk mencapai keadilan berkontrak dapat dilakukan dengan upaya pembinaan dan pengawasan, dalam hal ini tanggung jawab pembinaan berada pada pemerintah sebagaimana diatur dalam Pasal 28 UndangUndang Nomor 8 Tahun 1999 dengan membuat suatu kebijakan yang dapat membuat iklim hubungan para pihak dapat berjalan dengan baik. ${ }^{27}$ Untuk memenuhi tujuan dari Undang-Undang Perlindungan Konsumen sebagaimana dimaksud dalam Pasal 3 Undang-Undang Perlindungan Konsumen perlu dilakukan pembinaan dan pengawasan tehadap terselenggaranya perlindungan terhadap konsumen. Pembinaan terhadap pelaku usaha dilakukan untuk mendorong pelaku usaha supaya bertindak sesuai dengan aturan yang berlaku, baik aturan yang diharuskan oleh undang-undang, kebiasaan, maupun kepatutan, sehingga tercipta iklim usaha yang sehat dan tumbuhnya hubungan yang sehat antara pelaku usaha dan konsumen. Sedangkan pembinaan kepada konsumen diarahkan untuk meningkatkan sumber daya konsumen, sehingga mempunyai kesadaran yang kuat atas hak-haknya. ${ }^{28}$

Pasal 29 Undang-Undang Perlindungan Konsumen menyatakan bahwa tanggung jawab atas pembinaan penyelenggaraan perlindungan konsumen secara keseluruhan berada di tangan pemerintah yang dilaksanakan oleh menteri-menteri teknis terkait. Pelaku usaha sebagai produsen senantiasa harus diawasi supaya mereka bertindak sesuai dengan aturan yang berlaku, sehingga pelaku usaha benar-benar memenuhi kewajibannya. ${ }^{29}$ Menurut Pasal 30 ayat (1) UndangUndang Perlindungan Konsumen, pengawasan terhadap penyelenggaraan perlindungan konsumen serta penerapan ketentuan peraturan perundangundangan dilaksanakan oleh pemerintah, masyarakat, dan lembaga perlindungan konsumen swadaya masyarakat.

Berkaitan dengan larangan pencantuman klausula baku pada perjanjian baku, Pasal 52 butir c Undang-Undang Perlindungan Konsumen menentukan bahwa Badan Penyelesaian Sengketa Konsumen bertugas dan berwenang

27 Muhamad Hasan Muaziz, Pengaturan Klausula Baku dalam Hukum Perjanjian Untuk Mencapai Keadilan Berkontrak dalam www.academi.edu/22646514/pengaturan_klausula_baku_dalam_hukum_perjanjian, 20 Juni 2016.

${ }^{28}$ Janus Sidabalok, Op. Cit., hlm. 178.

${ }^{29}$ Loc.cit. 
melakukan pengawasan terhadap pencantuman klausula baku. Kontrak berlangganan sambungan telekomunikasi telepon selular pascabayar masih mencantumkan kalusula baku yang dilarang Pasal 18 Undang-Undang Perlindungan Konsumen, namun sampai sekarang belum ada tindakan dari BPSK untuk memanggil pelaku usaha yang diduga telah melakukan pelanggaran terhadap perlindungan konsumen, sehingga terkesan membiarkan hal itu terjadi.

Berdasarkan hasil penelitian diperoleh data dari BPSK kota Bandung bahwa pengaduan konsumen terkait kontrak berlangganan sambungan telekomunikasi telepon selular pascabayar hanya sedikit dan pada tahun 2016 hanya ada satu kasus yang diputus sampai tuntas oleh BPSK yang memutuskan bahwa pelaku usaha harus mengganti kerugian yang diderita oleh konsumen. Adapun kasus sejenis lainnya hanya sampai pengaduan dan pada saat akan diperiksa oleh BPSK, konsumen tidak datang kembali, sehingga pemeriksaan terhadap kasus tersebut tidak diteruskan. BPSK seharusnya memberikan sosialisasi kepada masyarakat, namun hal ini terkendala oleh biaya sebagaimana dijelaskan oleh petugas BPSK kota Bandung, sehingga selama ini hanya dilakukan satu kali sosialisasi UndangUndang Perlindungan Konsumen. ${ }^{30}$ Oleh karena itu, masyarakat kurang mengetahui hak-haknya sebagai konsumen dan pelaku usaha juga masih mencantumkan klausula baku yang dilarang Undang-Undang Perlindungan Konsumen. Lain halnya dengan kota Jakarta, menurut petugas di YLKI Jakarta, pengaduan konsumen yang cukup banyak adalah mengenai telekomunikasi, pengaduan kasus telepon selular pascabayar pun cenderung lebih banyak dibandingkan dengan pengaduan kasus yang lain dan penyelesaiannya dilakukan dengan mediasi. ${ }^{31}$ Sepanjang 2015 pengaduan mengenai telekomunikasi menduduki urutan ke 3, yaitu sebanyak 83 kasus $(8,06 \%) .{ }^{32}$ Berdasarkan uraian di atas, untuk menjamin tegaknya hak-hak konsumen sebagaimana diatur dalam undang-undang, serta dapat mencapai tujuan dari Undang-Undang Perlindungan

\footnotetext{
${ }^{30}$ Hasil wawancara dengan Dede Sopandi, petugas BPSK Kota Bandung.

${ }^{31}$ Hasil wawancara dengan Sularsi, petugas YLKI Jakarta.

32 Majalah Triwulan Konsumen Edisi 01/XLII/2016
} 
Konsumen, maka diperlukan upaya pemberdayaan konsumen. ${ }^{33}$ Hal ini dilakukan agar konsumen mempunyai kemampuan untuk menunjukkan diri dan ekistensinya sebagai konsumen, sehingga memahami apa yang menjadi kebutuhannya, memiliki kesadaran akan hak-hak dan kewajiban-kewajibannya sebagai konsumen dalam hubungan antara pelaku usaha dan konsumen.

Pemberdayaan konsumen yang sesuai asas keadilan dan keseimbangan tidak boleh merugikan kepentingan pelaku usaha. Hal ini dinyatakan juga dalam Penjelasan Umum Undang-Undang Perlindungan Konsumen, bahwa piranti hukum yang melindungi konsumen tidak dimaksudkan untuk mematikan usaha para pelaku usaha, tetapi sebaliknya melalui perlindungan konsumen tersebut dapat mendorong iklim berusaha yang sehat dan lahirnya perusahaan yang tangguh dalam menghadapi persaingan melalui penyediaan barang dan/atau jasa yang berkualitas. Pemberdayaan konsumen dapat dilakukan melalui usaha peningkatan kualitas pendidikan, sehingga mencapai tingkat kemampuan dan kesadaran yang cukup untuk memahami kebutuhannya dan melindungi dirinya dari faktor luar. Dari sisi produsen, pemberdayaan konsumen dapat dilakukan melalui penanaman sikap kepedulian produsen terhadap konsumen, mereka perlu menyadari, bahwa kelangsungan hidup usahanya sangat tergantung pada konsumen. Dari sisi masyarakat, dapat dilakukan melalui gerakan perlindungan konsumen dengan membentuk lembaga-lembaga swadaya masyarakat yang bergerak di bidang perlindungan konsumen. Di samping itu, diperlukan peran pemerintah dan pers, karena dukungannya sangat menentukan keberhasilan usaha pemberdayaan konsumen itu. ${ }^{34}$

Permasalahan yang dihadapi konsumen di Indonesia menyangkut pada penyadaran semua pihak, baik itu pengusaha, pemerintah maupun konsumen sendiri tentang pentingnya perlindungan konsumen. Kondisi saat ini, konsumen bersikap tidak mau repot, pemaaf dan mudah menerima, mempunyai bargaining power yang lemah, serta belum atau tidak berani berperkara. Pelaku usaha belum

\footnotetext{
${ }^{33}$ Pemberdayaan konsumen, yaitu usaha (atau gerakan) untuk melahirkan atau menciptakan konsumen yang mandiri dan memiliki sikap peduli melalui perilaku yang hati-hati di dalam berkonsumsi, Ibid, hlm 259 .

${ }^{34}$ Ibid., hlm. 260.
} 
semuanya menjalankan tanggung jawabnya, belum semuanya mengerti, memahami, serta mengimplementasikan Undang-Undang Perlindungan Konsumen. Kinerja kelembagaan belum efektif dan optimal, serta pemerintah kurang koordinatif. ${ }^{35}$ Dengan demikian, sebaiknya pengusaha menyadari bahwa mereka harus menghargai hak-hak konsumen. Pemerintah menyadari bahwa diperlukan undang-undang serta peraturan-peraturan di segala sektor yang berkaitan dengan berpindahnya barang dan jasa dari pengusaha ke konsumen, juga bertugas untuk mengawasi berjalannya peraturan serta undang-undang tersebut dengan baik. ${ }^{36}$ Demikian pula konsumen harus sadar akan hak-haknya sebagai seorang konsumen, lebih teliti, peduli dan kritis, sehingga dapat melakukan sosial kontrol terhadap perbuatan dan perilaku pengusaha dan pemerintah.

\section{Penutup}

Hasil penelitian menyimpulkan, pertama, Kontrak berlangganan sambungan telekomunikasi telepon selular pascabayar termasuk dalam perjanjian baku, karena telah memenuhi ciri-ciri perjanjian baku secara teoritis telah memenuhi ketentuan Pasal 1320 KUH Perdata mengenai syarat sahnya suatu perjanjian. Kedua, model kontrak berlangganan sambungan telekomunikasi telepon selular pasca bayar harus memuat klausul-klausul yang sesuai dengan Undang-Undang Perlindungan Konsumen, diantaranya bertujuan meningkatkan pemberdayaan konsumen dalam memilih, menentukan dan menuntut hak-haknya sebagai konsumen, menciptakan sistem perlindungan konsumen yang mengandung unsurkepastian hukum dan keterbukaan informasi serta akses untuk mendapatkan informasi, menumbuhkan kesadaran pelaku usaha mengenai pentingnya perlindungan konsumen, sehingga tumbuh sikap yang jujur dan bertanggung jawab dalam berusaha. Selain itu, tuntutan ganti kerugian konsumen tidak hanya atas dasar ingkar janji, tetapi seharusnya juga dapat dilakukan berdasarkan perbuatan melawan hukum

35 Makbullah Pasinringi, "Kebijakan Perlindungan Konsumen”, makalah disajikan pada Forum Komunikasi Teknis Bagi Anggota/Sekretariat BPSK, Makassar, 2008, hlm. 9.

36 Abdul Halim Barkatulah, Op. Cit., hlm. 18. 
sebagaimana diatur dalam Pasal 1365 KUH Perdata. Dengan berlakunya UndangUndang Perlindungan Konsumen, pembuatan perjanjian baku yang berisi klausula baku dibatasi dengan ketentuan Pasal 18 Undang-Undang Perlindungan Konsumen.

Rekomendasi peneliti antara lain: pertama, penggunaan klausula baku dalam kontrak berlangganan sambungan telekomunikasi telepon selular pascabayar harus ditinjau lagi dan disesuaikan dengan Undang-Undang Perlindungan Konsumen, sehingga masih diperlukan sosialisasi. Kedua, diperlukan upaya pemberdayaan konsumen, serta pembinaan dan pengawasan terhadap terselenggaranya perlindungan konsumen dan BPSK sebagai lembaga yang berwenang mengawasi pencantuman kalusula baku yang dilarang, diharapkan lebih meningkatkan perannya, sehingga kepada pelaku usaha yang mencantumkan klausula baku yang melanggar Pasal 18 Undang-Undang Perlindungan Konsumen dapat dikenakan sanksi dengan tegas yang dapat menimbulkan efek jera bagi pelaku bisnis lainnya.

\section{Daftar Pustaka}

Buku

Badrulzaman, Mariam Darus, Perjanjian Baku (Standard), Perkembangannya di Indonesia, Bandung, Alumni, 1980.

Barkatulah, Abdul Halim, Hukum Perlindungan Konsumen Kajian Teoritis dan Perkembangan Pemikiran, Nusa Media, Bandung, 2008.

HS, Salim, Perkembangan Hukum Kontrak di Luar KUH Perdata, PT Raja Grafindo Persada, Jakarta, 2006.

Miru, Ahmadi \& Sutarman Yodo, Hukum Perlindungan Konsumen, PT Raja Grafindo Persada, Jakarta, 2004.

Khairandy, Ridwan, Hukum Kontrak Indonesia dalam Perspektif Perbandingan, FH UII Press, Yogyakarta, 2014.

Siahaan, N. H. T., Hukum Konsumen Perlindungan Konsumen dan Tanggung Jawab Produk, Panta Rei, Jakarta, 2005.

Sidabalok, Janus, Hukum Perlindungan Konsumen di Indonesia, PT Citra Aditya Bakti, Bandung, 2006.

Soemitro, Ronny Hanitijo Metodologi Penelitian Hukum dan Juritmetri, Ghalia Indonesia, Jakarta, 1990. 
Sjahdeini, Sutan Remy, Kebebasan Berkontrak dan Perlindungan Yang Seimbang Bagi Para Pihak Dalam Perjanjian Kredit Bank Indonesia, Institut Bankir Indonesia, Jakarta, 1993.

Soekanto, Soerjono, Pengantar Penelitian Hukum, Universitas Indonesia Pers, Jakarta, 1986.

Sumardjono, Maria S.W., Pedoman Pembuatan Usulan Penelitian, Fakultas Hukum UGM, Yogyakarta, 1989.

\section{Hasil Penelitian/ Tugas Akhir/Makalah}

Heryati, Rini, Subaidah Ratna Juita, Ani Triwati, Perlindungan Hukum Bagi Konsumen Dalam Perjanjian Pembiayaan Konsumen (Suatu Kajian Normatif). Laporan Penelitian. Fakultas Hukum Universitas Semarang, 2011.

Iskandar, Christopher, Kekuatan Mengikat Klausula Syarat Batal Dalam Kontrak Bisnis Yang Mengesampingkan Pasal 1266 dan 1267 KUH Perdata, Tesis, Program Magister Ilmu Hukum Universitas Sumatera Utara, Medan, 2014.

Muaziz, Muhamad Hasan, Pengaturan Klausula Baku Dalam Hukum Perjanjian Untuk Mencapai Keadilan Berkontrak dalam www.academia.edu/22646514/ pengaturan-klausula-baku-dalam-hukum-perjanjian, 20 Juni 2016.

Pasinringi, Makbullah, "Kebijakan Perlindungan Konsumen”, makalah disajikan pada Forum Komunikasi Teknis Bagi Anggota/Sekretariat BPSK, Makassar, 2008.

\section{Artikel Jurnal}

Manda, I Kadek Mapra Bawa, "Aspek Hukum Berlangganan Telkom Flexy di Kota Palu", Jurnal Ilmu Hukum Legal Opinion, Edisi 4, Volume 3, Tahun 2015.

R.M. Panggabean, “Keabsahan Perjanjian dengan Klausul Baku” JURNAL HUKUM IUS QUIA IUSTUM, No. 4 Vol. 17, Oktober 2010.

Khairandy, Ridwan, "Iktikad Baik dalam Pelaksanaan Kontrak: Super Eminent Principle yang Memerlukan Pengertian dan Tolak Ukur Objektif" dalam JURNAL HUKUM IUS QUIA IUSTUM, Vol. 14, No. 3, Juli, 2007.

Paripurna P. Sugarda, "Kontrak Standar: Antara Prinsip Kehati-hatian Bank dan Perlindungan Nasabah Debitur" MIMBAR HUKUM Vol. 20, No. 2, Juni 2008.

\section{Majalah}

YLKI, Majalah Triwulanan Konsumen Panduan Kepercayaan Konsumen Edisi 01/XLII/2016.

Gunawan, Johanes, "Penggunaan Perjanjian Standar dan Implementasinya pada Asas Kebebasan Berkontrak", Majalah Pro Justitia, Universitas Katholik Parahyangan, Bandung, 1987. 


\section{Peraturan Perundang-Undangan}

Kitab Undang-Undang Hukum Perdata.

Undang-Undang Nomor 8 Tahun 1999 Tentang Perlindungan Konsumen (Lembaran Negara Republik Indonesia Tahun 1999 Nomor 42, Tambahan Lembaran Negara Republik Indonesia Nomor 3821). 